\title{
Criminal Justice System Toward Children With Legal Conflict Seen In Justice Restorative Presfective
}

\author{
Brian Septiadi Daud* and Irma Cahyaningtyas \\ Magister IImu Hukum, Universitas Diponegoro, Semarang-Indonesia \\ *bryanseptiady@gmail.com
}

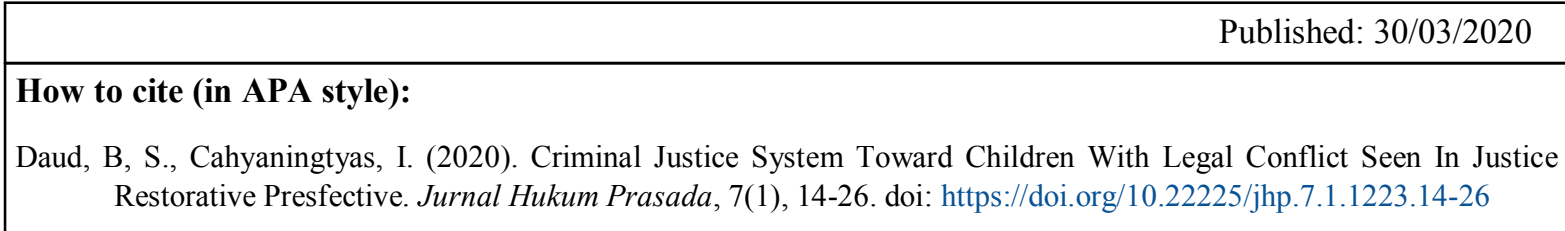

\begin{abstract}
The criminal justice system of children is very important in the effort to settle cases. Children are gifts of God that are entrusted to be cared for, guarded, and guided for a good future. In article 1 number 1 of Law no. 11 of 2012 states that what is meant by the juvenile justice system is the whole process of resolving cases of children dealing with the law from the investigation stage to the guidance stage after undergoing the crime. The aims of the study were to find out and analyze the juvenile justice system (SPPA) in conflict with the law and to examine the implementation of legal protection against children in conflict with the law based on Law Number 11 of 2012. The research method used to see the arrangement of this arrangement is juridical-normative legal research, this research is research that is attempted with the system reviewing applicable laws and regulations or applied to a particular legal case and concept. The method of collecting legal material with the document method is to collect library research contained in secondary legal materials, then analyzed deductively. The results of this study are to look at the process of the juvenile justice system based on subsystems, components, the process of achieving justice for restorative justice and the process of implementing child protection based on the applicable laws and regulations.
\end{abstract}

Keywords: Criminal Justice System for Children; Legal Conflict; Restorative Justice

\section{INTRODUCTION}

Indonesia is a state of law, where law becomes a means of solving problems to bring about justice. The criminal justice system (SPP) is essentially identical to the criminal law enforcement system (SPHP). The system of "law enforcement" is basically a "system of power / authority to enforce the law". In the process of law enforcement it reaches also to the making of law. The formulation of the mind of lawmakers as outlined in the rule of law will also determine how law enforcement is carried out.

The criminal system ( the sentencing system ) is a statutory regulation related to criminal sanctions and punishment (the statutory rules are related to reason sanctions and punishment ). The punishment system can be seen from a functional point of view and from the point of substance of the norms. From a functional angle it is interpreted as a whole system that regulates how criminal law is enforced in a concrete manner so that a person is subject to criminal sanctions. The penal system is thus identical to the criminal law enforcement system which consists of the substance of the material criminal law, the substance of the formal criminal law, and the legal implementation of the criminal law, this system is also interpreted as a criminal system in a broad sense.Viewed from the point of norms, the criminal system can be interpreted as a whole system of material criminal law norms for overthrowing and executing crimes. Criminal system in the sense of substance is defined as a criminal system in the narrow sense, namely concerning the issue of 
rules or provisions concerning criminal imposition.

In this case the term penalty is a general and conventional term, this term has a very broad and variable meaning, because it is related and connotes a very broad field. Therefore, the criminal justice system of children is very important in solving the case.

Children are a gift of God entrusted to be cared for, cared for, and guided for a good future. Children are also an investment that is of no value to their families or to the nation and state, because children are part of the nation's next generation. Children can also commit crimes due to various factors that encourage them to commit crimes. It is on this basis that the child needs to be protected from things that are detrimental to him, so that the child as the next generation of the nation is maintained for the future of the future (Gultom, 2008).

In Sri Ismawati's research entitled "Efforts to Protect Human Rights in the Coaching of Prisoners of Children (Studies in Penitentiaries for Class II B Children in Pontianak)" found the fact that in the LPAKelas II B Pontianak field, in providing protection for human rights in fostering child convicts, not yet implemented optimally (Ismawati, 2013).

The research conducted by Kadek Widiantari entitled "Legal Protection of Children in Conflict with Law Sentenced to Job Training Crimes" revealed that there were no implementing regulations regarding Job Training Crimes. Implementing regulations regarding Criminal Work Training are very important so that children's rights such as children's rights to develop, children's rights to get the best job training for the benefit of children, and children's rights to get training facilities can be protected properly (Widiantara, 2017).

In connection with the above, the Government of Indonesia is committed and gives special attention to the protection of children by participating in international convections on children organized by the United Nations (UN) such as the United Nations Standard Minimum Rules for the Administration of Juvenile Justice / SMRJJ (Beijing Rules ) and the Convention on the Rights of the Child, and the enactment of Law No. 3 of 1997 concerning Child Protection, then renewed with Law No. 11 of 2012 concerning the Child Criminal Justice System (SPPA)

As contained in Article 1 number 1 of Law No. 11 of 2012 states that what is meant by the juvenile justice system is the whole process of resolving child cases facing the law from the stage of investigation to the guiding stage after undergoing criminal proceedings.

As for how to settle child cases, in Law No. 3 of 1997 concerning the court of child formally has not stated the enactment of restorative justice, but in practice it has been implemented, namely by the settlement of cases in a family manner. UU no. 11 In 2012, the formal form of the juvenile justice system states that the implementation of restorative justice is stated (Article 11 point 6, Article 5 paragraph (1) jo . Paragraph (3)).

Based on the description above, aims of the study was to find out and analyze the juvenile justice system (SPPA) in conflict with the law and to examine the implementation of legal protection against children in conflict with the law based on Law Number 11 of 2012.

\section{METHOD}

The study was used to see the arrangement of this arrangement as juridicalnormative legal research, this research is research that is tried with the system of reviewing applicable laws and regulations or applied to a particular legal case and concept. Normative research, every time spoken with doctrinal research, is research whose object of study is a statutory document and library language. The approach used is a statute approach. The approach to legislation relating to per, which was adopted, was Law No. 11 of 2012 after which it was replaced by Law No. 20 of 2001 concerning the Child Criminal Justice System. The legal sources and materials used in this arrangement consist of primary legal materials, secondary legal materials, and tertiary legal materials. The method of collecting legal material with the document method is to collect library research contained in secondary legal materials. After that the information that has been collected next is analyzed in a qualitative manner supported by the logic of thinking deductively like 
an answer to all legal cases contained in this arrangement.

\section{RESULT AND DISCUSSION}

\section{Understanding the Judicial System}

The criminal justice system ( criminal justice system ) is a mechanism in dealing with crime that uses the basic system approach . In a system approach, use all the elements in which one has a unity and are interconnected, and influence each other. Through this approach, law enforcement officers, the police, the attorney's office, the court, and correctional institutions are important and interrelated elements. The criminal justice system is a system which is basically an open system, where a system in the movement achieves good goals, short-term goals (resocialization), medium term (crime prevention), and longterm (social welfare) that is strongly influenced by the community and the field of human life, then this criminal justice system will always experience an interface (interaction, interconnection, and interdependence) with the community environment, economy, politics, education, and technology, as well as the subsystems of the criminal justice system itself, the subsystem of criminal justice system . (Arief, 2011)

The legal system according to Friedman contains three elements namely, structure, substance, and legal culture. The three elements are a unity that cannot be separated because if one is released the system will change. (Tohir, 2011)

According to Muladi, the criminal justice system is a judicial network that uses criminal law as its main means, both material criminal law and formal criminal law. (Muladi, 2002) While Romli Atmasasmita distinguishes between the notions of "criminal justice processes" and "criminal justice systems". Criminal justice procces is every stage of a decision that confronts a suspect in a process that leads to the determination of the criminal for him, while the criminal justice system is an interconnection between the decisions of each agency involved in the criminal justice process.

\section{Purpose of the Criminal Justice System Muladi}

The criminal justice system is a network system ( network ) of the judiciary that uses criminal law as the main means in material criminal law, formal criminal law and the law of the implementation of criminal law. But substantial institutions must be seen in social contexts. This matter is too formal if it is based on the interests of legal certainty alone will lead to injustice.

\section{Mardjono Reksodiputro}

The justice system is a system of controlling crime that consists of institutions or institutions such as the police, prosecutors, courts, and prisons. It is stated that criminal justice system is a system in society to overcome crime. Countermeasures are defined as controlling crime in order to be within the limits of public tolerance. This tolerance becomes an awareness that evil will remain as long as there are people in society. Where there is a community there will be something called crime.

The purpose of the criminal justice system according to mardjono reksodiputro adalag is as follows:

Preventing people from becoming targets, objects or victims;

Resolve cases of crimes that occur in the community, and give satisfaction to the community that justice has been upheld and those guilty are convicted.

Endeavor those who commit crimes so as not to repeat their crimes.

\section{Juvenile justice system}

Lilik Mulyadi argues that in terms of the juridical aspect the notion of "child" in positive Indonesian law is defined as a person who is not yet an adult (minderjarig / person under age), a person who is underage or underage (minderjarigheid / inferiority) or often also referred to as children under the supervision of a guardian (minderjarige ondervoordij). Based on the aforementioned aspects it turns out that positive Indonesian 
law (lus constitutum / lus operatum) does not regulate the existence of standard legal unification and applies universally to determine the age limit criteria for a child. (Mulyadi, 2005)

Understanding children in Indonesian positive law there are several criteria including the following:

Criminal Code (KUHP)

In Article 45 of the Criminal Code it is explained that children are not yet mature if the child is not 16 (sixteen) years old. The provisions contained in Articles 45, 46 and 47 of the Criminal Code have not been valid and have been abolished by the issuance of Law No. 3 of 1997 which was later replaced by Law Number 11 of 2012 concerning the Child Criminal Justice System.

\section{Civil Code (Civil Code)}

Article 330 of the Civil Code states that children or minors are those who have not reached the age of 21 (twenty one) years and are not married first.

Law Number 1 of 1974 concerning the Principles of Marriage

Article 7 Paragraph (1) of Law Number 1 of 1974 concerning the Principal of Marriage states that a man is only permitted to marry if he has reached the age of 19 (nineteen) years and the woman has reached the age of 16 (sixteen) years. Deviations from this matter can only be requested for dispensation from the District Court.

Law Number 11 of 2012 concerning the Criminal Justice System for Children

Article 1 Number 3 of Law Number 11 of 2012 concerning Child Criminal Justice System formulates that Children Conflicting with Law, hereinafter referred to as Children, are children who are 12 (twelve) years old, but who are not 18 (eighteen) years of age. committing a crime.

\section{Law Number 35 of 2014 concerning Child Protection}

In Article 1 number 1 of Law Number 35 Year 2014 concerning Child Protection it is stated that the child is someone who is not yet 18 (eighteen) years old, including children who are still in the womb.

In article 1 number 1 Law No. 11 of 2012 states that what is meant by the juvenile justice system is the whole process of resolving child cases facing the law from the stage of investigation to the guiding stage after undergoing criminal proceedings.

Satjipto rahardjo in his book Law Science suggests a general understanding of systems. He said that the system is a complex unit consisting of parts that are related to each other. Such understanding only emphasizes the connection characteristics of the parts, but ignores the other characteristics, namely that the parts are jointly active to achieve the main goal of the unit. In a system that is placed in such a center of observation, the basic understanding contained in it is as follows: (Wiyono, 2016)

The system is goal oriented;

Whole is more than the sum of its parts (wholism);

Something the system interacts with a larger system whose environment (system openness);

The operation of the parts of the system creates something valuable (transformation);

Each part must be compatible with each other (connectedness);

There are unifying provisions that bind the system (control mechanism); follows:

The development of the understanding of the system that shows several meanings as

First, the understanding of the system used to refer to a set of ideas or ideas that are arranged, organized, and form a logical unity and then known as the ideas of certain philosophies, religions, or certain forms of government.

Second, the understanding of the system used for a group, or set, or unity ( unity ) of 
certain objects, which have a special relationship.

Third, understanding the system used in the sense of methods or procedures.

In Article 1 number 1 Law No. 11 of 2012, it can be seen that the Child Criminal Justice System has the following characteristics: form of;

The Child Criminal Justice System consists of components or sub- systems in the

Investigations carried out by investigators, namely RI state police officers as referred to in Law no. 2 of 2002 concerning the Indonesian National Police.

Prosecution carried out by the Public Prosecutor, namely the Prosecutor as referred to in Law No. 16 of 2004 concerning the Indonesian Attorney General's Office.

Examination in the trial conducted by the District Court as the First Level Court and the High Court as the Appellate Level Court, namely as referred to in Article 50 and Article 51 paragraph (1) of Law No. 2 of 1986 concerning the General Court.

Social Officers consisting of: (a) Community Guidance, (b) Professional Social Workers, (c) Social Welfare Workers as referred to in Article 63 of Law No. 23 of 2012 concerning the Child Criminal Justice System.

The components or subsystems of the juvenile justice system must carry out their duties and authorities to relate to each other in a pattern of interdependence as determined in following the Juvenile Judicial Procedure Law, namely in Chapter III of Law No. 11 of 2012.

Muladi, stated that in the criminal justice system, it is a material criminal law, formal criminal law, and criminal law. Property that is too formal if based on the k epentingan legal certainty alone, will bring disaster against injustice. (Wiyono, 2016)

Muladi emphasized the meaning of the integrated criminal justice system is synchronization or synchronization and harmony that can be distinguished namely in :

Structural synchronization ( structural syncronization ), which is harmony and harmony within the framework of relations between law enforcement agencies;

Substantial synchronization ( substantial syncronization ), namely simultaneity and harmony that are vertical and horizontal in relation to positive law;

Cultural synchronization ( cultural synchronization ), namely harmony and harmony in living the views, attitudes and philosophies that thoroughly underlie the running of the criminal justice system.

Overall juvenile criminal system is more than just the sum of the component component which in terms of its Criminal Justice System Children's most important is not about the quality of the components of the juvenile justice system as a whole. Mardjono Reksodipoetra , stated that there are 4 components in the criminal justice system, (the police, prosecutors, courts, and correctional institutions), are expected to establish cooperation and form an integrated criminal justice system. If there is no integration in the operation of this system, it can be estimated that there will be three losses as follows: tasks.

Difficulties in assessing the success or failure of each agency, related to their shared

Difficulties in solving themselves the main problems of each agency (as a subsystem of the criminal justice system).

Because the responsibilities of each agency are not clearly divided, each agency does not pay too much attention to the overall effectiveness of the criminal justice system.

In implementing the juvenile justice system , Law No. 23 of 2012 has provided several instructions as contained in article 2 and article 5 .

Article 2 and its explanation determine the juvenile justice system implemented based on the following principles.

Protection, which includes activities that are direct and indirect from actions that endanger the child physically / or psychologically. 

the child.

Justice, that is, every settlement of a child's case must reflect a sense of justice for

Non-discrimination, namely the absence of different treatment based on ethnicity, religion, race, class, gender, ethnicity, culture and language, legal status of children, birth order of children and physical and / or mental conditions.

The best interests of children, namely all decision making, must always consider the survival and development of the child.

Appreciation of children's opinions, namely respect for children's rights for the sake of and expressing their opinions in decision making, especially when it comes to matters that affect children's lives.

Survival and growth of children, namely the most basic human rights for children protected by the state, government, society, family, and parents.

Coaching, namely activities to improve quality, devotion to God Almighty, intellectuals, attitudes and behavior, training, skills, professionalism and physical and spiritual health of children, both inside and outside the criminal justice process.

Guidance, namely giving demands to improve the quality of piety to God Almighty, intellectual, attitude and behavior, skills training, professionalism, as well as physical and spiritual health of correctional clients.

\section{Justice in Restorative Justice}

In Law No. 3 of 1997 concerning the court of child formally has not stated the enactment of restorative justice, but in practice it has been implemented, namely by the settlement of cases in a family manner. UU no. 11 In 2012, the formal form of the juvenile justice system states that the implementation of restorative justice is stated (Article 1 point 6, Article 5 paragraph (1) ji. Paragraph (3)).

According to Muladi, restorative justice is a theory that emphasizes the recovery of losses will be achieved by the existence of cooperative processes and resolution. (Yunus, 2015)

For Manan, raging restorative justice is a confusing translation of restorative justice , due to the possibility of misleading : thinking that restorative justice is a type of justice, such as the teachings of justice ( attributive justice, distributive justice, social justice, etc.). Restorative justive indeed as a concept of punishment aims to find a way to enforce a more just and balanced criminal system. Like between the interests of the perpetrators and victims. However, restorative justice does not only formulate criminal objectives. And no less important is the mechanism in achieving goals. (Wiyono, 2016)

Restorative justive is the concept of punishment, but as a concept of punishment not only limited to the provisions of the law of the criminal ( formal and material ). Restorative justice must also be seen / observed from criminology and correctional systems.

From what Bagir Man stated, a number of things are known as follows:

Restorative justice cannot be thus simply translated as " restorative justice " or "' restorative court ";

Restorative justice is only a kind of justice such as various teachings about justice ( attributive justice, distributive justice, social justice, and others);

Restorative justice is a concept of punishment that aims to find a way to uphold a fair and balanced criminal system;

Restorative justice is a concept or way of resolving criminal acts ( acts ) outside of the judiciary ( out of criminal judicial procedure ) or not, not fully following the way of criminal justice;

Restorative justice is not limited to the provisions of criminal law (formal and material) but must also be seen from criminology and penal systems.

A simple definition of restorative justice is "victim, offender, and community - might be healed." 43 Basic principles include: (V , Mackey, 1990) 
Safety is the first consideration of the community. The first step toward restoration must be those who have suffered and those who are at risk to suffer at the hands of others.

The least dramatic interventions, forms of coercion, and social control consistent with public safety are always to be preferred in dealing with offenders. broken.

The primary focus is on the harms of wrongdoing rather than the laws that have been

Concern and commitment must be shown both to victims and to offenders, involving both in the process of justice.

Work toward the sense of violation, empowering them, and responding to their needs as they see them.

Offenders must be held accountable for their actions, expected to take responsibility for their behavior, and called upon to change.

Offender should be expected to make restitution whenever possible, not as a matter of punishment but an obligation and a means of helping to achieve restoration. possible.

The basic conflict that is led to harm should be addressed and resolved whenever

Affected communities need to be involved in the restorative justice process. They have a stake in its outcome. Such involvement will also increase their capacity to recognize and respond more effectively to those conditions and practices within their community that contributes to crime.

Options for treatment and treatment options in Indonesia.

The justice of restorative justice must be understood, requiring an effort to recover or recover losses from the consequences of a criminal act and the perpetrator is given the opportunity to be involved in the recovery effort, because all of that is in the context of maintaining community involvement and maintaining the creation of justice. (Prayitno, 2012)

In article 1 number 6 of Law No. 11 of 2012 concerning the juvenile justice system states that what is meant by restorative justice is the settlement of criminal cases by involving perpetrators, victims, families of perpetrators or families of victims, and other parties concerned to jointly seek a just solution by pressing on recovery the original situation and not for retaliation.

UU no. 11 of 2012 concerning the juvenile criminal justice system, where there are no provisions explaining further what is meant by "restorative justice", except in the explanation of Law No. 11 of 2012 stated that:

" Restorative justice is a diversion process, which means that all parties involved in a particular crime together solve the problem and create an obligation to make things better by involving victims, children and the community in finding solutions to improve, reconciliation, and reassuring hearts that are not based on retaliation. "

In the academic report on the Criminal Procedure Code on the Criminal Procedure Code for Children, it was stated that criminal justice for children with restorative justice has the purpose of: (Arief, 2012)

Seek peace between victims and children;

Prioritizing completion outside the process;

Keep children away from the negative influence of the judicial process;

Instill a sense of responsibility for children;

Me realize the welfare of children;

Avoid children from deprivation of liberty;

Encourage the community to participate;

Improve children's life skills.

International instruments on the protection of children's rights as set out in UN 
Resolution 44/25 dated November 20, 1989 concerning Conventions on The Rights of the Child, which are then regulated in UN Resolution 1386 / XIV, December 201959 concerning the Declaration of the Rights of the Child contains 10 (ten) basic principles, which include:

Children have the right to enjoy all their rights in accordance with the provisions contained in this Declaration. That every child without exception must be guaranteed their rights regardless of ethnicity, skin color, gender, language, religion, political views or other views, nationality or social level, rich in poverty, birth or other status, both of which he has and his family.

Children have the right to special protection, and must have the opportunity guaranteed by law and other means, in order to be able to develop themselves physically, psychologically, morally, spiritually and socially in healthy, normal situations according to their freedom and dignity.

Children from birth have the right to name and nationality.

Children have the right and must be guaranteed socially to grow and develop in a healthy manner.

Children who are physically, mentally disabled and have a weak social position due to certain conditions must receive education, care and special treatment;

In order for a child's personality to grow to its full potential and harmony, it needs affection and understanding. As much as possible he is raised under the care and responsibility of his own parents, and however it must be endeavored to remain in a loving atmosphere;

Children have the right to receive compulsory education for free at least at the elementary school level. They must get protection that can increase their general knowledge, or that allows them on the basis of equal opportunities to develop their abilities, personal opinions and feelings of moral and social responsibility so that they can become useful members of society. Children also have the freedom to play and recreation which is directed towards the purpose of education, the community and the government that have the authority to try to improve the implementation of this right;

Under any circumstances the child must take precedence in receiving protection and help;

Children must be protected from all forms of neglect, violence, exploitation. He should not be subjected to trafficking, meaning that a child may not work before a certain age, he must not be involved in work that can harm his health or education, or which can affect the development of the body, soul and behavior;

Children must be protected from acts that lead to forms of social discrimination, religion or other forms of discrimination.

These ten principles are declaratory statements which are more binding piece of international legislation, namely a provision that is more binding and detailed in nature and contained in the articles of the convention. Therefore, the basic principles of child protection are a reflection of an approach that is holistic in nature, meaning that children's rights are not seen narrowly, but must be seen broadly according to the scope of human rights protection, such as civil, political, economic rights, social and cultural. (Pasalbessy, 2015)

The introduction notes that are fundamental to any restorative justice definition and practice. First, crime is viewed as a conflict between individuals that results in injuries to victims, communities, and offenders themselves, and only secondarily as a violation against the state. Second, the aim of the criminal justice process should be to create peace in communities by reconciling the parties and repairing the injuries caused by the dispute. Third, the criminal justice process should facilitate active participation by victims, offenders, and their communities to find solutions to the conflict. Six papers discuss the theory for restorative justice practice; 5 address restorative justice practices among indigenous peoples; 8 examine restorative justice practice issues; and 11 papers consider restorative justice program applications. Detailed descriptions of Aboriginal restorative 
practices in various countries shows that current restorative justice approaches mirror ancient ways of settling disputes. Papers present restorative justice practices at various points in the justice system on the basis of referrals from prosecutors, judges, and probation and parole officials. In addition, one paper address dispute settlement between staff and inmates of a correctional institution, and another situation. Further, a paper describes a statewide effort to implement restorative justice systems within local systems. Restorative justice is often associated with victim and offender reconciliation programs. A number of papers examines such programs in various countries . (Hudson, Galaway, 1996)

\section{Implementation of Protection Against Children Conflicting with Law Based on Law No. 11 of 2012}

A person who violates criminal law will face the state through his law enforcement apparatus. As an instrument of social supervision, criminal law relies on sanctions because its function does indeed deprive people of their rights to life, freedom or property rights. Invasion of these basic rights is justified in order to preserve society and protect fundamental rights from interference from others.

According to Made Sadhi Astuti, there are several children's rights that need to be considered and fought for together, the rights of the child include:

Not become a victim in the criminal justice process;

Having the obligation to participate in upholding justice in a criminal justice process in accordance with their respective abilities to be fostered in order to be able to carry out their obligations as good citizens of the community by the authorities in the broadest sense;

To carry out the obligation of fostering, assisting peers to carry out their rights and obligations in a rational positive, responsible and beneficial manner in the process.

In completing child cases, children must be specifically enforced. This special protection is found in Article 17 paragraph (1) of the Child Criminal Justice System Act. This is because the nature and psychology of children in some cases require special treatment, as well as special protection as well, especially in actions that can harm the mental and physical development of the child.19 Special treatment begins at the stage of investigation, the examination of the child in the underage with adults. In conducting an investigation of a child's case, the Investigator is obliged to seek consideration or advice from the Community Guidance after the crime has been reported or complained.

Law No. 11 of 2012 concerning the Criminal Justice System for Children is made to give a sense of justice to children, to provide opportunities for children to participate in resolving conflicts, and to be responsible for what they have done, because there is diversion through a Restorative approach Justice who emphasized restoration to its original state. The process of applying through a restorative justice approach to criminal acts of theft by minors is different from the process of applying punishment in general. Restorative justice is not regulated in detail in the Criminal Justice System Law, but in Article 8 paragraph (1) of Law 11 of 2012 concerning the Child Criminal Justice System, it is explained that the diversion process is carried out through deliberation involving children and parents / guardian, victim and parent / guardian, Community Advisor, and Professional Social Worker based on the Restorative Justice approach. Explanation of Article 8 can be concluded that the application of restorative justice follows the mechanism of diversion, namely the transfer of law from criminal justice processes to processes outside of criminal justice. The process of legal transfer (diversion) will not work if it does not use restorative justice as a solution. Diversion occurs in every stage starting from the stage of investigation, prosecution, until the stage of the examination of child cases in the state court (Article 7 (1) of the Child Criminal Justice System Act).

The substance regulated in this law, among others, regarding the placement of children undergoing judicial proceedings can be placed in the Institute for Special Development of Children (LPKA). The most basic substance in this Law is the strict regulation of Restorative Justice and Diversion which is intended to avoid and distance children from the judicial process so that they can avoid stigmatizing children who are 
facing the law and are expected to be able to return to the social environment naturally, because it is very necessary the participation of all parties in order to realize this. The process aims at creating Restorative Justice, both for children and for victims. (Rochaeti, 2014)

This diversion process using the restorative justice approach is only used in cases of children whose criminal threat is under 7 (seven) years and is not a repetition (Article 7). In the process of enforcing child criminal law, the apparatus, whether investigators, public prosecutors and judges in conducting diversion must consider the category of criminal offenses, the age of the child, the results of community research from Bapas and the support of the family and community environment. In addition, in the event that it is needed, the meeting can also involve Social Welfare Workers, and / or the community. (Prasetyo, 2015)

The diversion process that must be considered:

The interests of the victim.

Child welfare and responsibility.

Avoid retaliation.

Harmonization in society.

Decency, decency, and public order.

In the case of investigations of minors in general, it is often found that there is coercion from the investigator to admit that he has stolen a criminal act, it can be concluded that children's rights are often not seen in the investigation phase, even though a child involved in a crime must be given special protection. In article 17 paragraph (1) it is written that the Investigator, Public Prosecutor and Judge are obliged to provide special protection for children who have been examined for crimes committed in an emergency situation. Investigators who conduct investigations on children in the concept of restorative justice must prioritize special treatment as written in Article 17. Special protection for children who are dealing with the law can also be seen in Article 59 of Law No. 23 of 2002 concerning Child Protection that "The government and other institutions are obliged and responsible to provide special protection to children who are in conflict with the law". Investigations conducted on children may not use the attributes of law enforcement as a general investigation. Because it can worsen the mental and psychological condition of children who are not ready to deal with the law. So that in the stage of implementing restorative justice, it is very necessary the role of the Community Guidance, Professional Social Workers, Social Welfare Workers. In the stage of detention against child offenders is not the same as detention in general. In Article 21 paragraph (1) of the Criminal Procedure Code (KUHAP) explains:

Allegedly committing a crime based on sufficient evidence;

In the event of a situation that raises concerns that the suspect or defendant will escape, damage, or lose evidence;

Repeat the crime;

In the practice of investigators or the Public Prosecutor and Judge conducting the detention, use the conditions specified in Article 21 paragraph (1) of the Criminal Procedure Code. Is a child who is underage then detained on the grounds that he will run away even though the child has a clear identity and family, or is it appropriate to hold a child caught stealing, and the evidence has been confiscated by the authorities. What is the relevance of making the detention requirements for suspects the concern of eliminating evidence, while the evidence has been confiscated by the authorities. The process of detention according to Article 32 paragraph (1) of the Child Criminal Justice System Law, detention of children should not be carried out in the event that the child obtains a guarantee from a parent / guardian and / or institution that the child will not run away, will not damage or eliminate goods evidence, and / or will not repeat the crime.

The stage after the investigation is prosecution, which is carried out by the public prosecutor. According to Article 42 paragraph (1) of the Law on the Criminal Justice 
System for Children that "the Public Prosecutor is obliged to work on Diversity no later than 7 (seven) days after receiving the case file from the investigator". At the prosecution stage the public prosecutor is obliged to work towards the transfer of the law in the best interest of the child offender through a restorative justice approach. In the event that the diversion process succeeds in reaching agreement, the public prosecutor submits the minutes of the diversion along with the agreement of the diversion to the chair of the District Court to make a decision. If in the case of diversion fails, the public prosecutor is obliged to deliver the minutes of the diversion and submit the case to the court by attaching a report on the results of community research.

Transfer of law through the Restorative Justice approach can be applied at the examination stage at the court session. According to Article 52 paragraph (2) the Child Criminal Justice System Law explains "Judges must seek diversion no later than seven days after being determined by the head of the state court as a judge". If the process of transferring the law ( diversion ) through a restorative justice approach succeeds in reaching an agreement, the judge conveys the news of the diversion to the head of the state court to make a determination. If the diversion fails, the case continues to the trial stage by maintaining a family atmosphere that is maintained, so that children can express all events and feelings openly and honestly during the trial.

The mechanism for resolving the application of Restorative Justice to criminal acts of theft by minors uses mediation or deliberation by emphasizing the restoration to its original state in resolving child conflicts. This deliberative settlement will not be realized if there is no collaboration between the victim, the criminal, the community and the investigator. Investigators or the police as the gateway to the juvenile justice system and the authorities first determine the position of a child in conflict with the law. The police must use the discretionary authority which is part of the process of transfer of law (diversion) which uses the restorative justice approach as a legal consideration in accordance with the law and the best interests of the child. Discretion is given to investigators to seek diversion by using the Restorative Justice approach. Discretion in the juvenile justice system is a policy of child investigators in determining a juvenile delinquency case, not followed by the examination with legal considerations in accordance with the legislation in the best interest of the child.

The discourse given by the state to one of these sub-judicial systems in carrying out the task of maintaining and protecting order and security in society and overcoming crimes, the specifications of perpetrators of theft by minors, these crimes are diverted ( diversion ) from formal to process informal, i.e. by using the concept of restorative justice, where the emphasis is on resolving conflicts or disputes by occupying victims, perpetrators and the community around the place of crime of theft committed by minors and facilitated by a mediator. Mediators (who mediate) generally involve a neutral third party (which is impartial), and wants to be heard by both parties. Who has extensive knowledge and is trained in child cases. Those who can become mediators can be Judges, Police, Prosecutors because the mediation process can be at all stages (can be linked to Article 7 paragraph (1) of the Child Criminal Justice System Law ). The purpose of this peace is that this dispute can forgive one another and not need to be brought to justice because both parties are satisfied with the mediation that has been carried out.

Mediation as a way in restorative justice, there are positive things in overcoming the theft of a criminal act, especially the crime of theft committed by minors, including:

The victim can express his complaints, his discomfort, on the other hand he can learn about the perpetrators, how to deal with the crime of theft, the opportunity and the right to get an apology and appropriate compensation from the perpetrator, showing the impact on the perpetrators of the actions, resolving all conflicts which is for personal gain or recovery.

For the perpetrator he has a sense of responsibility for what he did to the victim, and has the right to apologize and pay the victim's loss, social work according to the agreement agreed in the mediation process.

It can be seen above that restorative justice is very concerned about rebuilding relations after a crime has taken place. The form of agreement from the mediation process 
can be in the form of, peace, compensation for the victims, returning the stolen property, social work, service to the community, etc. (in accordance with the agreement).

In implementing the mechanism of the process of implementing restorative justice requires the desire to continue to provide protection for child offenders. However, because in the restorative process requires prior confession of guilt. After the guilty plea of the offender, the investigator must also look at the motivation of the perpetrator to commit a crime, whether this child is basically an evil person, and has previously carried out actions that harm other people, or in such a condition that there is an insistence on commit a crime.

One effective way in implementing Restorative Justice is that the police must create a special team that has been trained in handling problems concerning children, especially in cases of theft committed by children. So that the Police can directly deal with problems and mingle with the community. So they can know firsthand the problems that occur in the community and find solutions and solutions by using the mediation of the restorative justice approach through the diversion mechanism.

If in every case of theft committed by minors applying Restorative Justice, it can indirectly reduce children detained in detention and prison, and the reduction in cases that go to court, reduce the number of prisoners in institutions, reduce the state budget . If all perpetrators of crimes in this case theft, which is included in minor crimes committed by minors, then put into a correctional institution is very of no use value because it only has a negative impact on the child themselves. Children who are supposed to get guidance still need knowledge such as school and affection and then mingle with other prisoners who will only be contaminated from evil qualities. So that it can be said that the actual implementation of punishment is not right if a solution can still be found. What is really needed is in every problem that emerges, together with the community and law enforcement and both parties who are litigating must find a win-win solution for the small problems above, so that those who have high emotional states no longer report to law enforcement because can solve the problem with the right solution.

\section{CONCLUSION}

With the above description, it can be concluded that the juvenile justice system by implementing Restorative Justice can provide justice to the rights of children who are perpetrators and victims, such as providing or creating justice in a family or deliberation or settlement outside the court . This Restorative Justice can also fight for children's rights in the concept of a child protection law. Restorative justice can also be applied to children who commit theft, where this provides settlement of cases without having to go through a court. In other words this supports the settlement of cases against children through a process of deliberation or family.

In the provisions of Law Number 11 of 2011 concerning the Criminal Justice System the Child is made to give a sense of justice to the child, provide an opportunity for children to participate in resolving conflicts, and be responsible for what they have done, because there are diversions through approaches Restorative Justice which emphasizes restoration to its original state. Restorative justice is not regulated in detail in the Criminal Justice System Law, but in Article 8 paragraph (1) of Law 11 of 2012 concerning the Child Criminal Justice System, it is explained that the diversion process is carried out through deliberation involving children and parents / guardians, victims and their parents / guardians, Community Guidance, and Professional Social Workers based on a Restorative Justice approach. Explanation from Article 8 can be concluded that the application of restorative justice follows the mechanism of diversion, namely the transfer of law from the criminal justice process to the criminal justice process

\section{REFERENCES}

Arief, B, N. 2012. RUU Baru Sebuah Restrukturisasi Atau Rekonstruksi Sistem Hukum Pidana Indonesia, Semarang, Universitas Diponegoro Semarang.

Arief, B, N. 2011. Kapita Selekta Hukum Pidana, Sistem Peradilan Hukum Pidana Terpadu 
(Integrited Criminal Justice System), Semarang, Universitas Diponegoro Semarang.

J Hudson, B Galaway. 1996. Restorative Justice, International Perspectives, United States Of America: Criminal Justice Press.

Mackey, V. 1990. Restorative Justice: Toward Nonviolence. Louisville, KY: Presbyterian Criminal Justice Program, Presbyterian Cruch (USA).

Mulyadi, Lilik. 2005. Perlindungan Anak di Indonesia, (Teori, Praktik, dan Permasalahannya), Bandung, Mandar Maju.

Prasetyo, Teguh. Penerapan Diversi Terhadap Tindak Pidana Anak Dalam Sistem Peradilan Pidana Anak, Jurnal Refleksi Hukum, 2015.

R. Wiyono. 2016. Sistem Peradilan Pidana Anak, Jakarta Timur: Sinar Grafika.

John Dirk Pasalbessy, Implementasi Hak-Hak Anak Di Indonesia (Kajian terhadap usaha perlindungan anak dan korban kekerasan selama konflik di maluku), Jurnal Fakultas Hukum Universitas Patimura, 2015.

Kadek Widiantari, Perlindungan Hukum Terhadap Anak Yang Berkonflik Dengan Hukum Yang Dijatuhi Pidana Pelatihan Kerja, (Semarang, Jurnal Fakultas Hukum Universitas Diponegoro, Jilid 46 Nomor 4, 2017)

Kitab Undang-Undang Hukum Perdata (KUH Perdata)

Kitab Undang-Undang Hukum Pidana (KUHP)

Kuat Puji Prayitno, Restorative Justice Untuk Peradilan di Indonesia (Perspektif Yuridis Filosofis Dalam Penegakan Hukum In Concreto), Vol. 12. No. 3, September 2012.

Pasal 21 Ayat (1) Kitap Undang-Undang Hukum Acara Pidana (KUHAP).

Sri Ismawati, Upaya Perlindungan Hak Asasi Manusia dalam Pembinaan Narapidana Anak (Studi di Lembaga Pemasyarakatan Kelas II B Anak Pontianak), Semarang, Jurnal Masalah-Masalah Hukum, Fakultas Hukum Universitas Diponegoro, Jilid 42 No. 3, 2013.

Toto Tohir, Rekonstruksi Budaya Hukum Nasional Yang Berbasis Nilai-Nilai Budaya Hukum Bangsa Indonesia, Vol. XIII Nomor 1, 2011.

UU No. 11 tahun 2012 Tentang Sistem Peradilan Pidana Anak.

UU Nomor 35 Tahun 2014 tentang Perlindungan Anak

Yustirsa Yunus, Analisis Konsep Restorative Justice Melalui Sistem Diversi Dalam Sistem Peradilan Pidana Anak di Indonesia, Vol. 2, No. 2, Juni 2015, Jurnal Rects Vinding (Media Pembangunan Nasional). 